\title{
Fabrication of Novel Silk Fibroin - LDHs Composite Arhitectures for Potential Bone Tissue Engineering
}

\author{
BIANCA GALATEANU ${ }^{1,2}$, IONUT CRISTIAN RADU ${ }^{3}$, EUGENIA VASILE ${ }^{4}$, ARIANA HUDITA ${ }^{1}$, MIRELA VIOLETA SERBAN ${ }^{1}$, \\ MARIETA COSTACHE ${ }^{1}$, HORIA IOVU ${ }^{3}$, CATALIN ZAHARIA ${ }^{3 *}$ \\ IUniversity of Bucharest, Faculty of Biology, Department of Biochemistry and Molecular Biology, 91-95 Splaiul \\ Independentei, 050095, Bucharest, Romania \\ ${ }^{2}$ Research Institute of University of Bucharest, 36-46 M. Kogalniceanu Blvd., 050107, Bucharest, Romania \\ 3University Politehnica of Bucharest, Advanced Polymer Materials Group, 1-7 Gh. Polizu Str.,011061, Bucharest, Romania \\ ${ }^{4}$ University Politehnica of Bucharest, 313 Splaiul Independentei, 060042, Bucharest, Romania
}

\begin{abstract}
Nanocomposite materials have attracted a high interest for biomedical applications because their special properties related with structure and composition. In this paper we synthesized novel hydrogel nanocomposite materials special designed for hard tissue engineering. The nanocomposite materials are able to promote hydroxyapatite formation by alternating soaking mineralization demanded for increasing of cells biocompatibilityand adhesion.
\end{abstract}

Keywords: nanocomposite, hydroxyapatite, hydrogel, silk, tissue engineering

Nanocomposite hydrogels are three-dimensional (3D) network structures formed by the combination of a natural or synthetic polymer and an inorganic reinforcing agent. They combine the unique properties of a polymeric hydrogel which is capable of absorbing large quantities of water with extraordinary higher stretching ability, strength, stiffness and resistance exhibited by the inorganic phase [1-2]. Polymeric 3D networks based on natural or synthetic polymer have been widely investigated because their valuable applications in biomedical fields. However hydrogels have some limitations in terms of mechanical properties, the tensile properties, like limited stretching ability and brittleness $[3,4]$. This brittleness could be attributed to the traditionally organic cross-linkers, which are capable to attach only several polymer chains due to their limited functionality. These types of cross-linkers can achieve only a small number of bridges between polymer chains in relation with their functionality. In these conditions, the improvement of the mechanical properties is achieved by adding the inorganic reinforcing agents [ 1 , 5]. Furthermore, biopolymer based nanocomposites have attracted much interest for biomedical applications. In comparison with conventional micro-composites, the nanocomposites possess special properties which are attributed to their nanometric size range and better dispersion properties in polymeric matrix. The nanometric size range assure a higher specific surface which leads to the formation of stronger organic-inorganic phase interactions [5-7]. Furthermore, inorganic reinforcing fillers such as clay have a smooth nonporous surface area which can lead to strong physic bonds with polymeric phase [89]. The hydroxytalcite-like material layered double hydroxide take part from one of the larger groups of synthetic and natural layered materials. They have an overall positive charged sheet, resulted by the replacement of some divalent ions with trivalent ions. The positively charge sheets are compensated by the incorporation of exchangeable anions $[9,10]$. Because of their anionic exchange capacity and ability to incorporate long-chain organic anions, the layered double hydroxides (LDHs) are one of the most used reinforcing fillers. Furthermore, layered double hydroxides have a facile synthesis, a very varied and flexible composition and a high biocompatibility and biodegradability $[5,11,12]$. These unique properties made this type of clay very attractive for many biomedical applications. They were used in controlled drug delivery application like antibacterial and anti-inflammatory drug release systems[13-15], cancer therapy[16,17], adsorbents [18], sensors [19] and bionanocomposite materials. For the design of LDH-based bionanocomposite materials and biohybrid materials have been used a wide range of biopolymeric matrixes such as casein, starch, alginate, pectin or carrageenan. These biopolymers were successfully interlaced between LDH layers using several methods like ion exchange, co-precipitation, delaminationrestacking or reconstruction methods [5].

Silk fibroin (SF) is a naturally-occurring biopolymer, one of the tw o major components of the silk fibers. Silk fibroin is an insoluble protein containing mainly three types of aminoacids: glycine, alanine and serine [20,21]. Fibroin is a hydrophobic structural protein consisting in a heavy molecular chain with molecular weight of about 325.000 $\mathrm{Da}$ and a light chain with a molecular weight of about 25.000 Da. Natural polymers such as silk fibroin generally exhibit a better biocompatibility and biodegradability when compared with synthetic polymers. Thereby, silk fibroin became a crucial natural polymer for biomedical applications due to its special ability to sustain tissue regeneration through a good interaction with cells. SF has been intensively used for the design of conventional nontoxic, non-carcinogenic and biodegradable 3D scaffolds for tissue engineering [22, 23].

The design of silk fibroin based hydrogels usually consists in blends of natural and synthetic polymers. The natural polymer is responsible with a high biocompatibility and biodegradability, while the synthetic polymer comes with better mechanical properties. Poly(acrylic acid) (PAA) is one of the most used synthetic polymer for controlled synthesis of inorganic-organic hybrid materials specially in hydroxyapatite biomineralization process. PAA is one of

\footnotetext{
*email: zaharia.catalin@gmail.com
} 
the common water-soluble polymers possessing carboxylate $(\mathrm{COOH})$ groups that generate acidic macromolecules. The carboxylate groups present of the chains backbone provide a control on nucleation process, growth, morphology, structure and crystal orientation [24, 25].

The present study is focused on the development of a novel nanocomposite hydrogel for bone tissue engineering, with specific mechanical properties required by the bone tissue particularities. The novel nanocomposite hydrogel was designed for the restauration of hard tissues, which demand intermediate mechanical properties, achieved by hydrogel reinforcing with a modified mineral clay.

\section{Experimental part}

Materials and methods

Preparation of silk fibroin solution

The raw silk fibers were obtained from native $B$. mori silkworms provided by. The silk fibroin obtained from $B$. mori cocoons following: Silk fibers were degummed by washing four times in aqueous solution of $\mathrm{Na}_{2} \mathrm{CO}_{3} \mathrm{NaHCO}_{3}$ and sodium dodecyl sulfate at $100^{\circ} \mathrm{C}$. A solution of $\mathrm{CaCl}$ in water with a concentration about $9.3 \mathrm{M}$ was obtained. The degummed silk fibroin was dissolved in $30 \mathrm{~mL}$ of $\mathrm{CaCl}_{2}$ to obtain a silk fibroin concentration of 3\%. The silk fibroin solution was dialyzed in distilled water for 4 days with cellulose tubular membranes (molecular weight cut-off 1200). Acrylic acid monomer, $\mathrm{Na}_{2} \mathrm{CO}_{3}, \mathrm{NaHCO}_{3}$ sodium dodecyl sulfate, $\mathrm{CaCl}, \mathrm{N}, \mathrm{N}^{\prime}$-methylenebisacrylamide and potassium persulfate were supplied from Sigma Aldrich.

Obtaining of modified layered double hydroxide (LDH-SDS)

The modified mineral clay, layered double hydroxide with dodecyl sodium sulfate (LDH-SDS) was obtained by coprecipitation method [26]. A solution of $\mathrm{Mg}\left(\mathrm{NO}_{3}\right)_{2}, 6 \mathrm{H}_{2} \mathrm{O}$ $(9.6 \mathrm{~g})$ and $\mathrm{Al}\left(\mathrm{NO}_{3}\right)_{3} .9 \mathrm{H}_{2} \mathrm{O}(4.7 \mathrm{~g})$ in $\mathrm{H}_{2} \mathrm{O}(45 \mathrm{~mL})$ was obtained. A second solution was obtained by dissolving

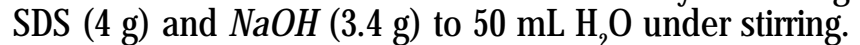
The $\mathrm{pH}$ value was maintained around 10 and the mixture was stirred $22 \mathrm{~h}$ at $80^{\circ} \mathrm{C}$. The precipitate was filtered and washed with $2 \mathrm{~L}$ of hot water $\left(80^{\circ} \mathrm{C}\right)$. The washed precipitate was dried for $48 \mathrm{~h}$ at $80^{\circ} \mathrm{C}$.

Preparation of SF/polyacrylic acid/LDH-SDS nanocomposite hydrogels

The present study is focused on the designing of nanocomposite hydrogels based on polymeric matrix (silk fibroin and polyacrylic acid) and an inorganic phase based on modified mineral clay type double layered double hydroxides. Nanocomposite hydrogels are materials consisting in organic-inorganic network with enhanced mechanical properties which have been widely studied with regard to the synthesis, network structure, mechanical properties, swelling behavior and intercalation/exfoliation process [1].

The nanocomposite hydrogels were prepared using various ratios between acrylic acid monomer $(25 \% \mathrm{w} / \mathrm{v}$ in water) and preformed protein silk fibroin (ratio silk fibroin/ acrylic acid: 10/90; 20/80; 30/70; 40/60 and 50/50), crosslinked with $N, N^{\prime}$-methylenebisacrylamide $(3 \% \mathrm{w} / \mathrm{w})$. The specimens were further denoted by SF/PAAC: 10/90, SF/PAAC: 20/80, SF/PAAC: 39/70. SF/PAAC: 40/60, SF/PAAC: 50/50. The inorganic phase represented by sodium dodecyl sulfate modified clay with different amount $(0,1,3$ and $5 \% \mathrm{w} / \mathrm{v}$ ) was added in the aqueous solution mixture of the initiator (potassium persulfate), acrylic acid and silk fibroin. Then, free-radical polymerization reaction was allow ed by heating the mixture at $60^{\circ} \mathrm{C}$ for $72 \mathrm{~h}$.
The ratio between acrylic acid monomer and silk fibroin, and modified clay concentrations were varied at a time in order to highlight the influence of these parameters. The hydrogel samples were synthetized in paralellipipedic glass matrix of $10 \mathrm{~cm}$ length and $0.75 \mathrm{~cm}$ high, which assure the obtaining of samples required for mechanical, rheological and swelling tests. After $72 \mathrm{~h}$ the nanocomposite hydrogel samples were submerged in distilled water for 3 days for monomer extraction and purifying.

Preparation of SF/polyacrylic acid/LDH-SDS lyophilizednanocomposite hydrogels

The samples were previously swollen in distilled water for $30 \mathrm{~h}$ and then were frozen at $-50^{\circ} \mathrm{C}$ for $24 \mathrm{~h}$. The main drying was performed at $-40{ }^{\circ} \mathrm{C}, 0.4 \mathrm{mbar}$ (vacuum) for 24 $\mathrm{h}$ leading to lyophilized specimens.

\section{Swelling behavior}

The swelling tests were carried out by immersing the prepared hydrogels and nanocomposite hydrogels specimens in a volume of $50 \mathrm{~mL} \mathrm{NaCl}$ queous solution (0.9\%). Experiments were performed in triplicates at $37^{\circ} \mathrm{C}$ for 2 days. The degree of swelling (DS) is represented by the ratio of the weight of the swollen water with weight of the corresponding dried hydrogel.

$$
D S(\%)=\frac{W_{s}}{M_{0}}
$$

where $\mathrm{W}_{\text {is }}$ is the difference between the weight of the swollen hydrogel at time $t, W_{T}$, and weight of the dried hydrogel $W_{0}$.

$$
W_{s}=W_{\tau}-W_{0}
$$

Alternating soakingbiomineralization tests

The rapid biomineralization tests were performed according to Taguchi method of alternate soaking process [2]. The lyophilized and non-lyophilized nanocomposite hydrogel samples were immersed for 2 days in two alternating mineralization solutions. In the first day, each swollen sample was immersed in $25 \mathrm{~mL}$ aqueous solution of $\mathrm{CaCl}_{2}(200 \mathrm{mM}) / \mathrm{Tris}-\mathrm{HCl}(\mathrm{pH} 7.4)$ at $37^{\circ} \mathrm{C}$ for $24 \mathrm{~h}$, followed by rinsing with distilled water. After washing, the calcium-covered samples were immersed in aqueous solution of $\mathrm{Na}_{2} \mathrm{HPO}_{4}(120 \mathrm{mM})$ for another $24 \mathrm{~h}$ at $37^{\circ} \mathrm{C}$.

$5 \mathrm{CaCl}_{2}+3 \mathrm{Na}_{2} \mathrm{HPO}_{4}+2 \mathrm{H}_{2} \mathrm{O} \rightarrow \mathrm{Ca}_{5}\left(\mathrm{PO}_{4}\right)_{3} \mathrm{OH}+6 \mathrm{NaCl}+4 \mathrm{HCl}$

Reaction of hydroxyapatite formation

The biomineralized specimens were washed with deionized water and dried at room temperature for $48 \mathrm{~h}$. Samples with mineral deposits on the surface were milled and subjected to X-ray analysis to examine the crystalline structure of the hydroxyapatite.

The biomimetic process involves a substrate with acidic groups capable of binding the $\mathrm{Ca}^{2+}$ ions and control nucleation and growth of the crystals. The biomineralization process is described in figure 1 .

The XRD patterns were registered on a Panalytical $X ' P E R T$ MPD X-ray Diffractometer, in the range $2 \theta=10-$ 80. An X-ray beam characteristic to $\mathrm{Cu} \mathrm{K} \alpha$ radiation was used $(\lambda=1.5418 \AA)$.

Scanning electron microscopy characterization (SEM)

Morphological information on lyophilized hydrogel samples was taken on a Quanta Inspect F SEM device equipped with a field emission gun (FEG) with $1.2 \mathrm{~nm}$ 


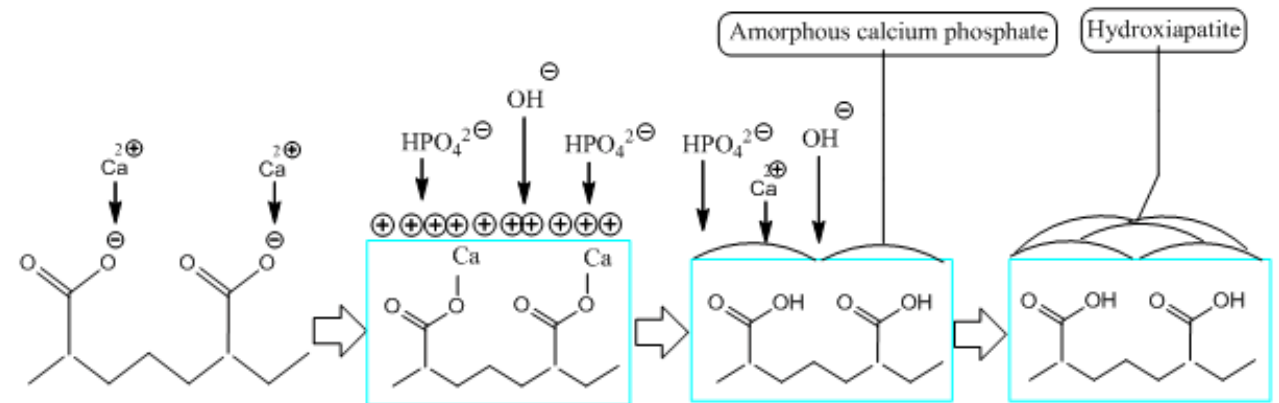

Fig.1.Biomineralization process of the hydroxyapatite nucleation

resolution and with an X-ray energy dispersive spectrometer (EDS). SEM images highlight both porous structure formed after lyophilization process and morphological structure of the hydroxyapatite formed by alternating soaking biomineralization process. To highlightthe influence of the modified inorganic clay in rapid biomineralization process, were characterized both nanocomposite hydrogel samples involving two phases, organic-inorganic, and hydrogel samples without modified mineral clay. The rapid biomineralization tests were performed in order to stimulate hydroxyapatite (HA) nucleation and formation within the samples. Thereby, the rapid biomineralization methods imply the hydroxyapatite deposition on the substrate before samples being introduced into the body.

\section{In vitro biocompatibility evaluation}

3T3-E1 mouse preosteoblastic cell line (American Type Culture Collection) was employed in this study. Cells were cultured in Dulbecco's modified Eagle's Medium (DMEM), supplemented with $10 \%(\mathrm{v} / \mathrm{v})$ fetal bovine serum (FBS) and $1 \%(\mathrm{v} / \mathrm{v})$ penicillin/streptomycin $(10,000$ units/mL penicillin and $10 \mathrm{mg} / \mathrm{mL}$ streptomycin) and incubated at $37^{\circ} \mathrm{C}$ in a humidified atmosphere of $5 \% \mathrm{CO}_{2}$.

In parallel, the lyophilized SF/PAA hydrogels with the following compositions: 10/90; 20/80; 30/70; 40/60 and $50 / 50$ were sterilized by $24 \mathrm{~h}$ exposure to UV light on both sides. Next, the biomaterials were allowed to swell in sterile PBS buffer for $48 \mathrm{~h}$, at $4^{\circ} \mathrm{C}$.

3T3-E1 cells survival inside the porous scaffolds was evaluated after the achievement of 3D cell/scaffold bioconstructs. In this view, after propagation, 3T3-E1 were detached from the plastic surface by trypsin-EDTA treatment and seeded at an initial cell density of $10^{6}$ cells/ sample on top of each hydrogel. Cells were allowed to penetrate the porous scaffold and to attach to the biomaterial for $30 \mathrm{~min}$ and then the samples were incubated in complete DMEM culture medium in standard conditions of culture.

Cell survival was evaluated at $24 \mathrm{~h}$ and 7 days post seeding by Live/Dead fluorescence microscopy assay. This test consists in the concomitant staining of both the living and dead cells within a 3D culture. Briefly, Live/Dead kit (Life Technologies) was used to stain the living cells with calcein (green fluorescence) and the dead cell with ethidium bromide (red fluorescence). The staining solution was prepared according to the manufacturer's indications and the samples were stained for $1 \mathrm{~h}$ at room temperature and darkness. The fluorescence microscopy images were captured using an Olympus IX73 inverted microscope with fluorescence modulus.

\section{Results and discussions \\ Swelling behavior}

The swelling behavior of semi-IPN hydrogels is shown in figure 2. Samples were immersed in a aqueous solution of $\mathrm{NaCl} 0.9 \%$ at $37^{\circ} \mathrm{C}$ in order to obtain the equilibrium and degree of swelling (DS). The experiment results exhibit that the equilibrium was reached within about $31 \mathrm{~h}$ for all semi-IPN compositions both hydrogels and nanocomposite hydrogels. The swelling behavior of the
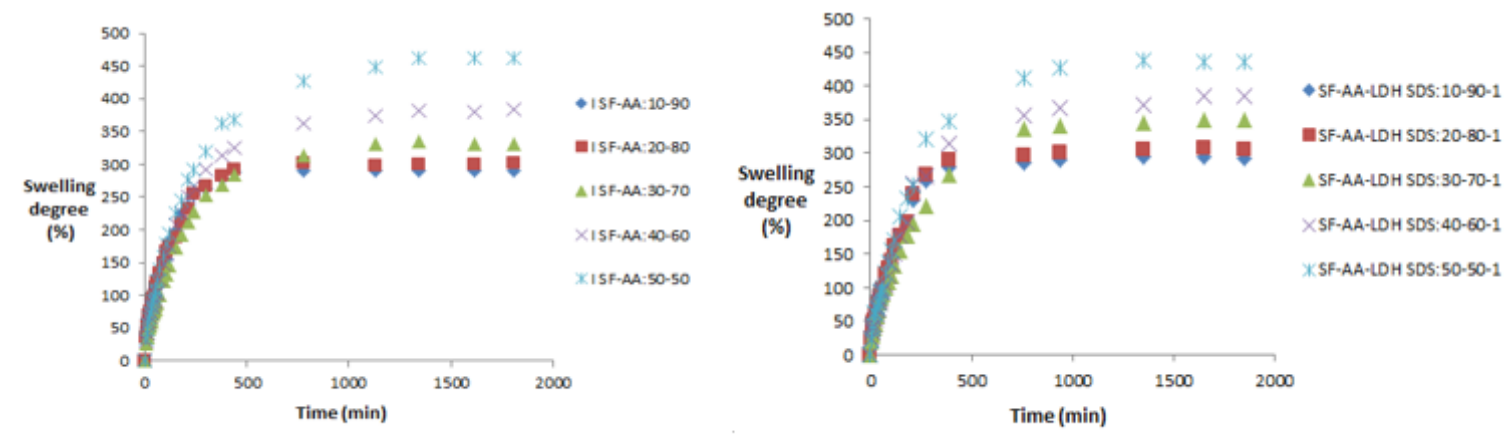

Fig.2 Swelling degree
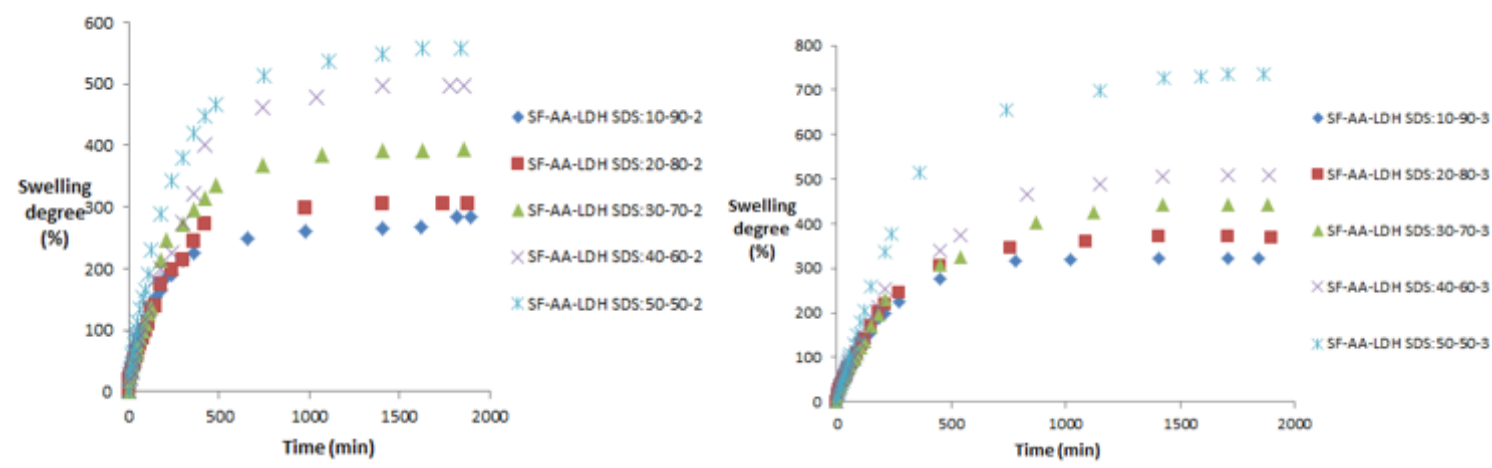

http://www.revmaterialeplastice.ro 
hydrogels and nanocomposite hydrogels showed an increasing trend of degree of swelling within the decrease of the acrylic acid amount. This behavior is sustained by fact that the crosslinking agent was added in ratio within acrylic acid monomer. A smaller amount of the crosslinking agent lead to formation of a hydrogel with a less crosslinking density and a less compact structure. In these conditions, the hydrogel canuptake rapidly a bigger amount of deionized-water or other aqueous solutions. Furthermore, the swelling tests highlight an increasing swelling degree within modified mineral clay amount (LDH-SDS). The LDH is a layered mineral clay which possesses many hydroxyl groups on surface and a lot of hydroxyl groups and water molecules between layers. Thereby, the presence of the hydroxyl groups give it a hydrophilic character, a required behavior in the swelling process. This process can be analyzed with a water-penetrating mechanism and kinetics. When a water-soluble 3D polymer network structure is brought into contact with water or aqueous solutions, the water molecules needs continuously to overcome the osmotic pressure inside the hydrogel. A higher osmotic pressure will determinate a slow permeation, a slow swelling rate through hydrogel and opposite. The penetrating mechanism can be described by both controlled molecules diffusion and controlled chain relaxation. At the beginning of the swelling process the osmotic pressure caused by the low chain elasticity of the hydrogel is verylow. Thus, the swelling rate is higher at the beginning and decreases within gradually increases of the hydrogel elasticity [17, 26]. Furthermore, the mechanism can be analyzed by the equation:

$\frac{M_{t}}{M_{\alpha}}=k \cdot t^{n}$, where $M_{t}$ and $M_{\alpha}$, represent the amount of water swelled at time $\mathrm{t}$ and at equilibrium. $\mathrm{k}$ is a characteristic constant of the hydrogel and $n$ is a characteristic exponent of the molecules transport model. The value of is used to determinate the transport mechanism. For $\leq 5$, the Fickian diffusion will dominate the transport mechanism, if the $\geq 5$, the chain relaxation will control the transport mechanism. The value of $n$ is calculated by plotting the equation in log $M_{t} / M_{\alpha}$ versus in logt:

$$
\log \left(\frac{M_{t}}{M_{\alpha}}\right)=\log (k)+n \log (t)
$$

The swelling kinetic results exhibit the fact that characteristic exponent which describe the molecules transport model takes values up than 0.5 for all sample compositions. The results show that the solute mechanism transport is anomalous and is dominated by the chains relaxation. The characteristic exponent values (table 1) tend to increase within amount of the silk fibroin and in the same time tent to increase within amount of the LDS-SDS. The coefficient of determination values, $R^{2}$ were up than 0.99 and show that the linear correlation of the swelling data was good.

\section{Alternating soaking biomineralization (SEM)}

To obtain the morphological structure of the formed hydroxyapatite, the biomineralized samples were morphologically characterized by Scanning electron microscopy. Hydroxyapatite is the main inorganic component of the bones and teeth with high bioactivity and good osteoconductive properties [28-29]. Obtaining and depositing of the hydroxyapatite crystals on a substrate are one of the main concerns of the researchers. The biomineralization process presented in figure 3 , reveals formation of the hydroxyapatite on the samples surface and inside the samples by alternate soaking process. Porous structure of the samples generated by the lyophilization process lead to improving of the hydroxyapatite crystallization and crystals growing. SEM images show the formation of some plate-type structures, which are representative for hydroxyapatite morphology. The morphological results are supported by X-ray diffraction analyzes which assume that all the main peaks attributed to hydroxyapatite are present in diffractogram. Furthermore, the morphological images reveal that the hydroxyapatite formation occurred not only on small areas but on the whole samples surface. These results indicate that formation of the hydroxyapatite layers on the nanocomposite samples can provide favorable conditions for the synthetic materials to bond the articular cartilage with the living bone.

\section{Morphological characterization (SEM)}

The structural arrangement of the porous nanocomposite materials is highlight by Scanning electron microscopy (fig.4). The special structural arrangement with pores formation was led by a lyophilization process. The yophilization assume that the water molecules pass from solid state to gaseous state and diffuses through sample in

Table 1

CHARACTERISTIC EXPONENT OF THE TRANSPORT MODEL VALUES-N AND COEFFICIENT OF DETERMINATION FOR THE REGRESSION MODEL-R²

\begin{tabular}{|c|c|c|c|c|c|c|c|c|c|c|}
\hline Nr. & $\begin{array}{c}\text { SF-AA-: } \\
10-90\end{array}$ & $\begin{array}{c}\text { SF-AA-: } \\
20-80\end{array}$ & $\begin{array}{c}\text { SF-AA: } \\
30-70\end{array}$ & $\begin{array}{c}\text { SF-AA: } \\
40-60\end{array}$ & $\begin{array}{c}\text { SF-AA: } \\
50-50\end{array}$ & $\begin{array}{l}\text { SF-AA- } \\
\text { LDH: } \\
10-90-1\end{array}$ & $\begin{array}{l}\text { SF-AA- } \\
\text { LDH: } \\
20-80-1\end{array}$ & $\begin{array}{l}\text { SF-AA- } \\
\text { LDH: } \\
30-70-1\end{array}$ & $\begin{array}{l}\text { SF-AA- } \\
\text { LDH: } \\
40-60-1\end{array}$ & $\begin{array}{c}\text { SF-AA- } \\
\text { LDH: } \\
50-50-1\end{array}$ \\
\hline $\mathrm{n}$ & 0.523 & 0.502 & 0.574 & 0.573 & 0.578 & 0.605 & 0.580 & 0.618 & 0.610 & 0.637 \\
\hline $\mathrm{R}^{2}$ & 0.9909 & 0.9934 & 0.9900 & 0.9908 & 0.9914 & 0.9964 & 0.9954 & 0.9936 & 0.9909 & 0.9925 \\
\hline \multirow[t]{2}{*}{ Nr. } & $\begin{array}{l}\text { SF-AA- } \\
\text { LDH: }\end{array}$ & $\begin{array}{l}\text { SF-AA- } \\
\text { LDH: }\end{array}$ & $\begin{array}{l}\text { SF-AA- } \\
\text { LDH: }\end{array}$ & $\begin{array}{l}\text { SF-AA- } \\
\text { LDH: }\end{array}$ & $\begin{array}{l}\text { SF-AA- } \\
\text { LDH: }\end{array}$ & $\begin{array}{l}\text { SF-AA- } \\
\text { LDH: }\end{array}$ & $\begin{array}{l}\text { SF-AA- } \\
\text { LDH: }\end{array}$ & $\begin{array}{l}\text { SF-AA- } \\
\text { LDH: }\end{array}$ & $\begin{array}{l}\text { SF-AA- } \\
\text { LDH: }\end{array}$ & $\begin{array}{l}\text { SF-AA- } \\
\text { LDH: }\end{array}$ \\
\hline & $10-90-2$ & $20-80-2$ & $30-70-2$ & $40-60-2$ & $50-50-2$ & $10-90-3$ & $20-80-3$ & $30-70-3$ & $40-60-3$ & $50-50-3$ \\
\hline $\mathrm{n}$ & 0.6182 & 0.656 & 0.679 & 0.709 & 0.675 & 0.641 & 0.696 & 0.6684 & 0.696 & 0.897 \\
\hline $\mathrm{R}^{2}$ & 0.9959 & 0.994 & 0.9946 & 0.9928 & 0.9922 & 0.9926 & 0.9954 & 0.9910 & 0.9934 & 0.9983 \\
\hline
\end{tabular}



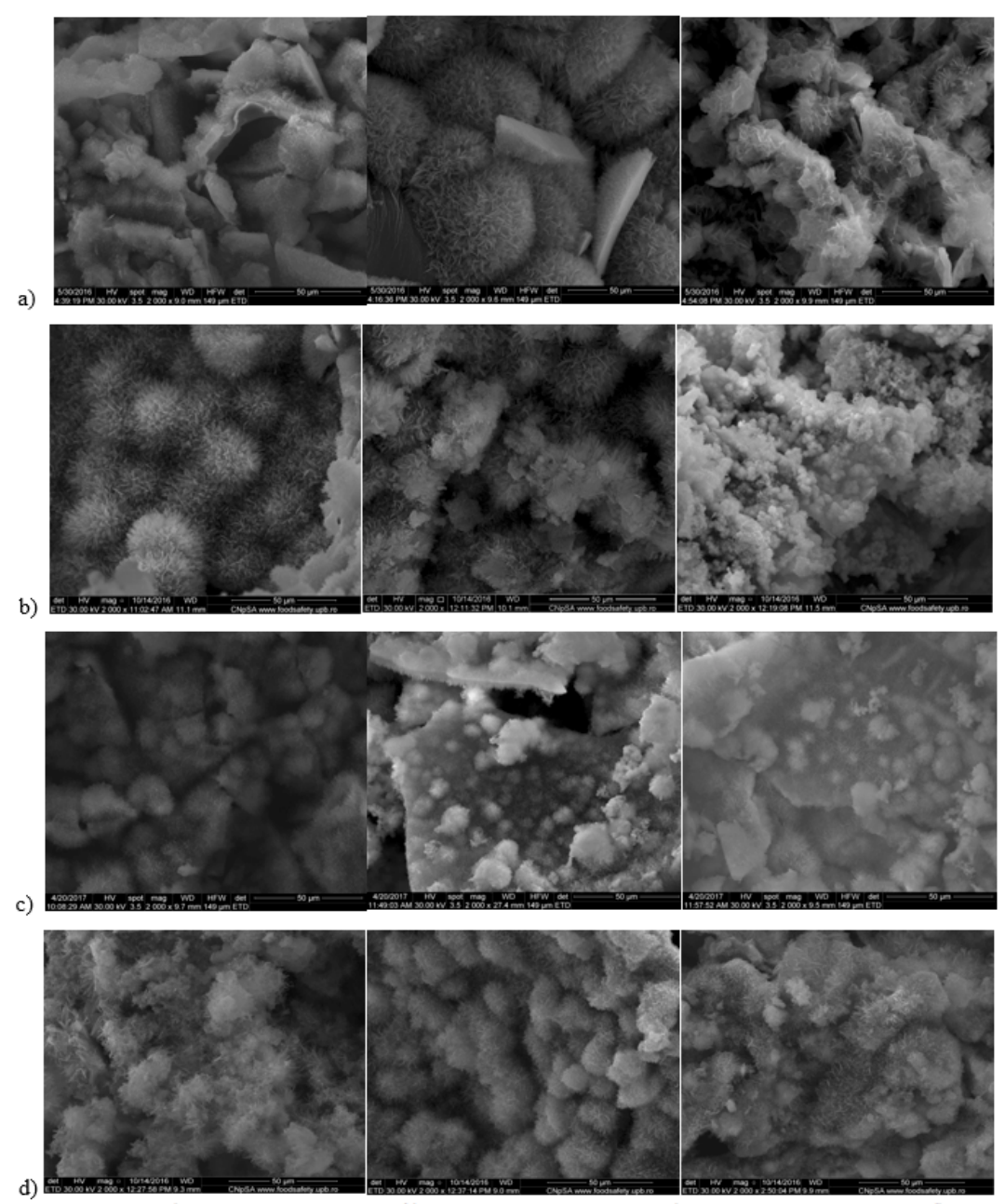

a)
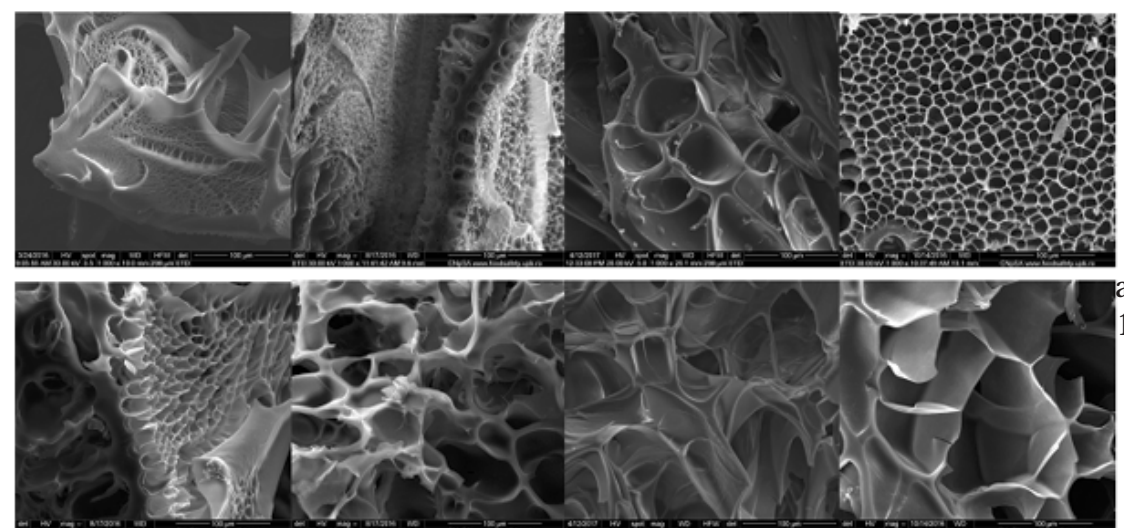

Fig.3 SEM images of the biomineralized samples: a) Samples with silk fibroin/acrylic acid: 10/90; 30/ 70; 50/50 ratio without LDH-SDS; b)Samples with silk fibroin/acrylic acid: 10/90; 30/70; 50/50 ratio with LDH-SDS 1\%; c) Samples with silk fibroin/ acrylic acid: 10/90; 30/70; 50/50 ratio with LDH-SDS 2\%; d) Samples with silk fibroin/acrylic acid: 10/ 90; 30/70; 50/50 ratio with LDH-SDS 3\%; low-pressure conditions. During diffusion process the water molecules lead to the formation of pores with different dimensions. Figure 4 shows the SEM images for samples SF-PAA with compositions 10/90 and 50/50, and for nanocomposite samples SF-PAA-LDH (1, 2, and 3\% LDH) with compositions $10 / 90$ and 50/50. The morphological images reveals that the clay amount does not influences the pores dimension and distribution for samples with the same compositions. The pores dimension seems to increase within amount of fibroin from SF-PAA compositions $10 / 90$ to $50 / 50$. This is because the crosslinking agent was added in ratio with acrylic acid monomer and the cross-linking density decrease within amount of fibroin leading to a less compact structure. The images show that pores dimension distribution is a large one. There are large pores with dimensions of tens of $\mu \mathrm{m}$ and small pores with dimension about 1 to $5 \mu \mathrm{m}$ which design the walls to the large ones. This pores dimension distribution has a great significance in processes of tissue regeneration because the large pores allow entrapping of the cells inside them and the small pores allow diffusion of water, nutrients and developing of the capillary blood vessels.

\section{$X$-ray diffraction characterization (XRD)}

The obtaining of hydroxyapatite by a biomimetic method with alternate rapid solutions was performed to promote the growth of crystals on the nanocomposite surface. During time, many techniques have been investigated to obtain hydroxyapatite crystals on/in a substrate. The first biomimetic process was developed by Kokubo T., where the crystals were obtained in a simulated body fluid. This method assumes obtaining of a simulated body fluid with ion concentrations comparable to those of a human blood plasma [30,31]. The other technique was the alternate soaking process, which led to the uniform coverage with hydroxyapatite [32]. XRD diffractograms (fig.5) of the mineralized nanocomposite samples confirmed the hydroxyapatite formation. Figure 5 shows the main peaks of the crystalline phase attributed to the 


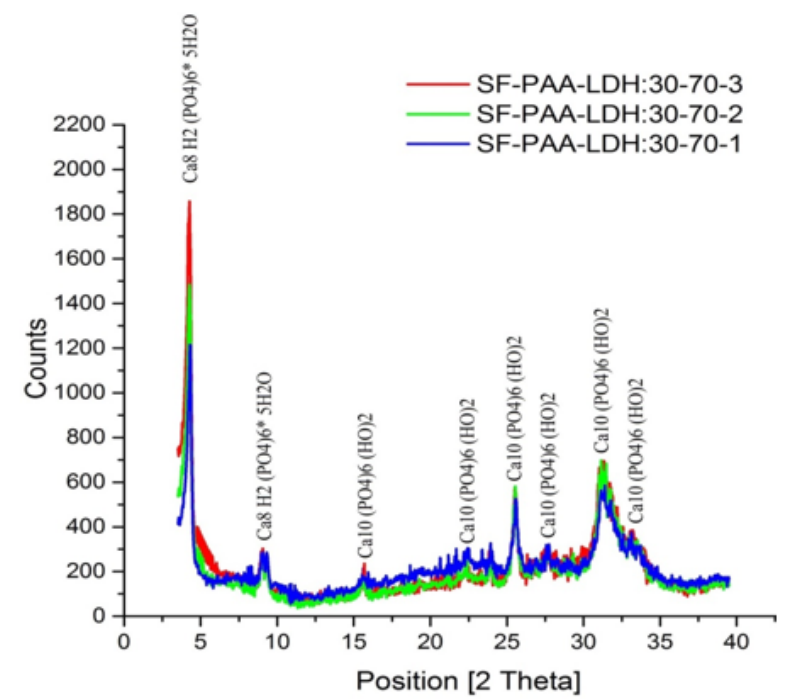

Fig.5 XRD diffractograms of nanocomposite hydrogel samples

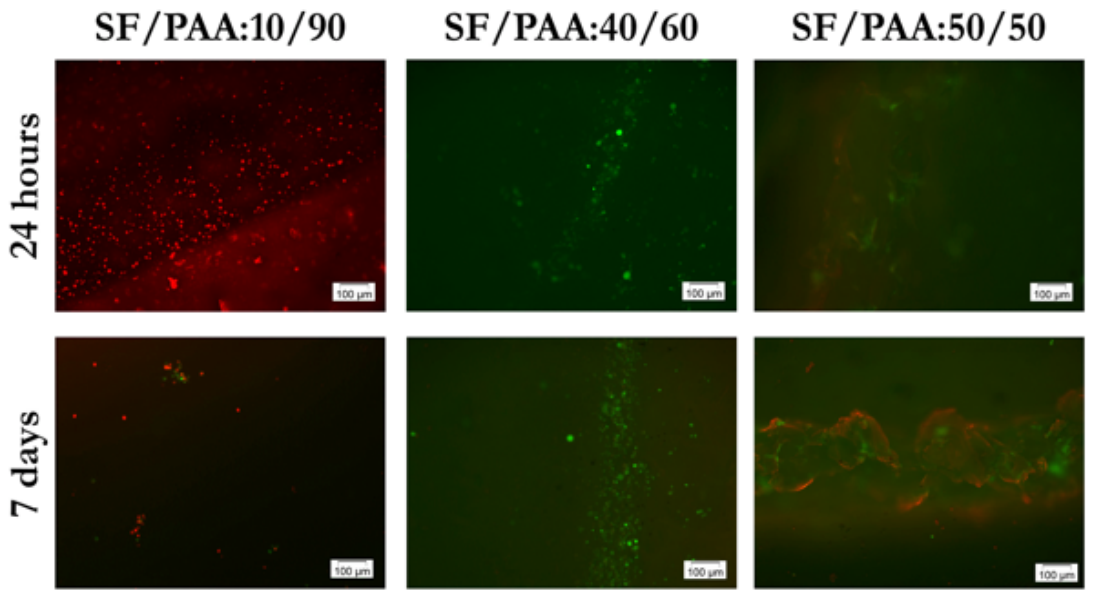

Fig. 6 Fluorescence microscopy images of 3T3Elcells stained with calcein (living cells green fluorescence) and ethidium bromide (dead cells red fluorescence), after $24 \mathrm{~h}$ and 7 days of culture inside porous SF/polyacrylic acid hydrogels

hydroxyapatite obtained by co-precipitation at the $2016.84^{\circ}$, $21.77^{\circ}, 22.86^{\circ}, 25.35^{\circ}, 25.86^{\circ}, 28^{\circ}, 31.77^{\circ}, 32.18^{\circ}$ and $32.91^{\circ}$ corresponding to planes (101), (200), (111), (201), (002), (102), (211), (300) and (202) respectively. Furthermore, the diffractograms of mineralized nanocomposites reveal two intense peaks at $4.72^{\circ}$ and $9.44^{\circ}$, which can be attributed to another calcium phosphate crystalline phase named calcium hydrogen phosphate hydrate $\left(\mathrm{Ca}_{8} \mathrm{H}_{2}\left(\mathrm{PO}_{4}\right)_{6}\right.$ $\left.5 \mathrm{H}_{2} \mathrm{O}\right)$. The two peaks correspond to diffraction planes $(010),(110)$ and are the only peaks attributed to calcium hydrogen phosphate hydrate crystalline phase.

Mouse preosteoblastic cells survival inside the SF/ polyacrylic acid/LDH-SDS lyophilized-nanocomposite hydrogels

After $24 \mathrm{~h}$ and 7 days of culture, 3T3-E1 cells viability was investigated inside the porous scaffolds by fluorescence microscopy after the concomitant staining of both living and dead cells within the 3D samples. As shown in figure 6,3T3-E1 cells din not survive inside the samples with low silk fibroin. However, the cell viability increased with the concentration of the natural silk fibroin component in the system, probably due to its role in modulating the scaffold's architecture. Consequently, the ration between the living and the dead cells inside the compositions containing 40/60 and 50/50 SF and polyacrylic acid was in the favor of the living cells. However, only cells inside the hydrogel with the highest concentration of silk fibroin displayed an elongated shape as a proof of their attachment to the substrate material.

\section{Conclusions}

The in vitro testing of the samples biocompatibility showed that the 3T3-E1 mouse preosteoblastic cells survival inside the proposed hydrogels increased with the concentration of the silk fibroin component in the system, despite the very good biocompatibility properties of each individual component used. SF/PAA: 40/60 and 50/50 sustained cells viability, but only the cells grown in contact with the SF/PAA: 50/50 displayed a characteristic morphology. Consequently, we concluded that the composition containing 50/50 SF and PAA would be suitable for further studies to evaluate its potential to sustain the osteogenic differentiation potential of the 3T3-E1 mouse preosteoblastic cells in vitro.

Acknowledgements: This research was financed by the University of Bucharest Research Institute (ICUB), through "Young Researchers Grant, competition 2016" Project 15568/01.07.2016.

\section{References}

1.QIMING WANG, ZHEMING GAO, J ournal of the Mechanics and Physics of Solids, vol. 94, 2016, p. 127-147.

2. E. KAYALVIZHY, P. PAZHANISAMY, International J ournal of Biological Macromolecules, vol. 86, 2016, p. 721-727.

3. KAZUTOSHI HARAGUCHI, HUAN-JUN LI, YING]IA XU, GUANG LI, Polymer, vol. 96, 2016, p. 94-103.

4. JIANFENG SHEN, NA LI, MINGXIN YE, Applied Clay Science, vol. 103, 2015, p. 40-45.

5. MEHDI YADOLLAHI, HASSAN NAMAZI, J. Nanopart. Res., vol. 15, 2013, p. 1563-1572. 
6. AEE-YOUNG PARK, HAEJINKWON, AE JA WOO, SUNG-JIN KIM, Advanced Materials, vol. 17, 2005, p. 106-109.

7.JIANFENG SHEN, NA LI, MINGXIN YE, Applied Clay Science, vol. 103, 2015 , p. 40-45.

8. NERMIN ORAKDOGEN, TALIN BOYACI, Reactive and Functional Polymers, vol. 102, 2016, p. 82-92.

9. SITI NURASIKIN AHMAD, NORHAYATI HASHIM, NURHIDAYAH YUSRI, ILLYAS MD ISA, AZLAN KAMARI, AZMI MOHAMED, MUHAMMAD IBRAHIM MOHD DAMANHUR, Nano Hybrids, vol. 7, 2014, p 53-67.

10.DEBDIPTA BASUA, AMIT DASA, KLAUS WERNER STÖCKELHUBERA,UDOWAGENKNECHTA, GERT HEINRICHA, ProgresS in Polymer Science, vol. 39, (2014), p. 594-626.

11. COSTA F.R., LEUTERITZ A., WAGENKNECHT U., JEHNICHEN D., HÄUßLER L., HEINRICH G., Appl. Clay Sci., vol. 38, 2008, p. 153-164. 12. DU L., QU B., ZHANG M., ,Polym. Degrad. And Stability., vol. 92, 2007, p.497-502.

13.AMBROGI, V., FARDELLA, G., GRANDOLINI, G., Int. J.Pharm., vol. 220, 2001, p. 23-32.

14.DEL ARCO, M., CEBADERA, E., GUTIÉRREZ, S., MARTÍN, C., MONTERO, M.J ., RIVES, V., ROCHA, J., SEVILLA, M.A, J. Pharm. Sci. 93, 2004, p. 1649-1658.

15.AMBROGI,V., FARDELLA,G.,GRANDOLINI, G.,NOCCHETTI, M., PERIOLI, L., J. Pharm. Sci., vol. 92, 2003, p. 1407-1418.

16. TYNER, K.M.,GIANNELIS, E.P., Arch. Appl. Biomater. Biomol. Mater.,vol.1, 2004, p. 449-451.

17. WANG, Z.L., WANG, E.B., GAO, L., XU, L., J. Solid State Chem., vol, 178,2005, p.736-741.

18.F. BRUNA, R. CELIS, I. PAVLOVIC, C. BARRIGA, C. CORNEJ O, M.A. ULIBARRI, J. Hazard. Mater., vol. 168, 2009, pp. 1476-1481.

19. I.M. ISA, N. M. SOHAIMI, HASHIM, N.A. KAMARI, A. MOHAMED, M. AHMAD, S.A. GHANI, SUYANTA, Int. J. Electrochem. Sci., vol. 8,2013, p. 2112-2121.

20.TIANYI ZHONGA, ZHIJUANJIANGA, PENG WANGA, SHIYU BIEA, FENG ZHANG, BAOQI ZUO, International Journal of Pharmaceutics, vol. 494,2015 , p. 264-270.
21.B.N. SINGH, N.N. PANDA, R. MUND, K. PRAMANIK, Carbohydrate Polymers, vol. 151, 2016, p. 335-347.

22. TERIN ADALIA, MURAT UNCUB, International J ournal of Biological Macromolecules, vol. 90, 2016, p. 11-19.

23. YE RI PARKA, HYUNG W OO JUA, JUNG MIN LEEA, DONG-KYU KIM (MD), OK JOO LEEA, BO M IMOONA, HYUN JUNG PARKA, JU YEON JEONGA, YEUNG KYUYEONA, CHAN HUM PARK, International J ournal of Biological Macromolecules, vol. 93, 2016, p.1567-1574.

24. NORIO WADA, NAOHIRO HORIUCHI, MIHO NAKAMURA, KOSUKE NOZAKI, TETSUO HIYAMA, AKIKO NAGAI, KIMIHIRO YAMASHITA, J ournal of Crystal Growth, vol. 415, 2015, p. 7-14.

25.NORIO WADA, MIHO NAKAMURA, YUMI TANAKA, KIYOSHI KANAMURA, KIMIHIRO YAMASHITA, J ournal of Colloid and Interface Science, vol. 330, 2009, p. 374-379.

26. TAO, Q., ET AL, Applied Surface Science, vol. 255, 2009, p. 43344340.

27. SEON JEONG KIM, KI JUNG LEE, IN YOUNG KIM, YOUNG MOO LEE, SUN I. KIM, Journal of Applied Polymer Science, vol. 90, 2003, p. 3310-3313.

28. Z.X. ZHAO, Z. LI, Q.B. XIA, E. BAJALIS, H.X. XI, Y.S. LIN, Chemical Engineering J ournal, vol. 142, 2008, p. 263-270.

29. WANPEN TACHABOONYAKIAT, TAKESHI SERIZAWA, MITSURU AKASHY, Polymer J ournal, vol. 33, 2001, p. 177-181.

30. JING ING WU, J IAOYAN LIU, YANMEI SHI, YING WAN, J ournal of the Mechanical Behavior of Biomedical Materials, vol. 64, 2016, p. 161172.

31. M. KAWASHITA, M. NAKAO, M. MINODA, H.-M. KIM, T. BEPPU, T. MIYAMOTO,T. KOKUBO, T. NAKAMURA, Biomaterials, vol. 24, 2003, p. 2477-2484.

32. AYAKO OYANEA, MASAKAZU KAWASHITAA, KAZUKI NAKANISHIA, TADASHI KOKUBOA,MASAHIKO MINODAB, TAKEAKI MIYAMOTOC, TAKASHI NAKAMURA, Biomaterials, vol. 24, 2003, p. 729-1735.

33. TAGUCHI TETSUSHI, KISHIDA AKIO, AKASHI MITSURU, Chemistry Letters, vol. 8, 1998, p. 711-712.

34. CASTRO, N.J ., HACKING, S.A., ZHANG., L.G., Annals of biomedical engineering, vol. 40, 2012, p. 1628-40.

$\overline{\text { Manuscript received: } 12.06 .2017}$ 